\title{
Epitope Mapping of Mono- and Polyclonal Antibodies by Screening Phage-displayed Random Peptide Libraries
}

\section{Peter Molek and Tomaž Bratkovič*}

\author{
University of Ljubljana, Faculty of Pharmacy, Department of Pharmaceutical Biology, Aškerčeva 7, \\ 1000 Ljubljana, Slovenia \\ * Corresponding author: E-mail: tomaz.bratkovic@ffa.uni-lj.si
}

Received: 22-03-2016

\begin{abstract}
Detailed knowledge of antigenic determinants is crucial when characterizing therapeutic and diagnostic antibodies, assessing vaccine effectiveness and developing epitope-based vaccines. Most epitope mapping approaches are labor intensive and costly. In this study, we evaluated panning of phage-displayed random peptide libraries against antibodies as a tool for cognate epitope identification. We used six antibodies directed to three model protein antigens as targets to show that the approach is applicable to both mono- and polyclonal antibodies. The technique is well-suited especially for identification of linear epitopes. Mapping of conformational epitopes is more challenging, tends to be more subjective and requires use of computational tools. Nevertheless, when combined with functional data such as structure-activity relationship of antigen muteins, one can make reliable conformational epitope predictions based on phage display experiment data. As the described approach is fast and relatively inexpensive, we suggest it is employed early in antibody characterization and later validated by complementary methods.
\end{abstract}

Keywords: Peptide, epitope mapping, mimotope, phage display, antibody

\section{Introduction}

Proteins generally make good immunogens owing to their structural complexity and relatively high molecular mass. Furthermore, in contrast to lipids, nucleic acids and polysaccharides, proteins elicit strong humoral responses due to involvement of helper $T$ cells in stimulation of lymphocytes B to become antibody-producing plasma cells. It is thus not surprising that most antigens are proteins in nature. Protein-derived B cell antigenic determinants can be fairly large with a surface area of above $1000 \AA^{2} .{ }^{1}$ However, only a handful of amino acid residues typically engage into energetically relevant interactions with the antibody binding site, constituting the so called functional epitope. ${ }^{2}$ Such an epitope is considered linear if its residues are arranged in sequential fashion. If, on the other hand, the hot-spot residues are located on separate regions of primary structure but are brought into close proximity by specific polypeptide chain fold, the epitope is regarded as conformational (or discontinuous). Detailed understanding of proteins' epitopes is essential for characterization of therapeutic antibodies ${ }^{3,4}$ and design of epitope-based vaccines. ${ }^{5}$ In addition, epitope mapping enables insight into vaccine effectiveness. ${ }^{6}$
There are a number of experimental approaches for identifying epitopes to which antibodies are directed (reviewed in $\mathrm{ref}^{7}$ ). Co-crystallization and determination of antigen-antibody complex structure represents the gold standard of epitope mapping as it is the most informative, but it often fails and is costly. ${ }^{8}$ Systematic site-directed mutagenesis and subsequent analysis of antibody-mutein interaction strength can also provide detailed information on epitope structure, but is very laborious. ${ }^{9}$ Another approach, called epitope excision, relies on limited proteolysis of the antigen when bound to an antibody, shielding it from the protease, and identification of resulting peptides by mass spectrometry. ${ }^{10}$ A related method, termed epitope extraction, is based on initial partial digestion of the free antigen and subsequent capture of resulting peptides by immobilized antibodies. ${ }^{10}$ Both techniques require fairly sophisticated equipment and can only identify linear epitopes. Combinatorial approaches for mapping epitopes were also described. Geysen et al. developed a procedure dubbed pepscan, wherein the antigen is broken down to a series of overlapping synthetic peptides and the fragments are analyzed for antibody binding using enzyme-linked immunosorbent assay 
(ELISA). ${ }^{11}$ Alternatively, antigen gene fragments can be cloned into a phage display vector to be expressed on the viral capsid. ${ }^{12}$ Gene fragment library is than panned against an antibody to enrich for linear peptide epitopes. Both, pepscan and gene fragment phage libraries are individual antigen-specific and need to be constructed anew for each antigen. Finally, phage display libraries of random peptides are also used for epitope mapping. ${ }^{13}$ Compared to synthetic peptide libraries, biological libraries can be several-fold larger; therefore even for a phage library of random peptides there is a reasonably high likelihood of containing epitope mimetics. A convenient feature of random peptide libraries is that they are universal (i.e., a single one can be applied to mapping epitopes of antibodies directed against diverse antigens). Although only linear epitopes can be unambiguously identified in this manner, there are computational approaches that can aid in mapping peptide epitope mimetics to three-dimensional structure of protein antigens. ${ }^{14,15}$

Vendors of commercial antibodies often do not characterize their products in terms of exact epitopes that the antibodies recognize or this information is not disclosed to customers. Yet, there are times when knowing the binding site of an antibody is crucial, e.g. to avoid competition for the same determinant in two-site immunoassays. Here, we present data on epitope mapping by random peptide phage library screening of six commercial antibodies ( 2 monoclonal and 4 polyclonal) directed against three model polypeptides: chemokine CCL2 and adipokine leptin (two proteins with compact fold), and ghrelin, a peptide hormone with poorly defined secondary structure in aqueous solutions. Affinity selections against all six antibodies yielded peptide epitope mimetics that were in turn aligned to antigen structure. We demonstrate that the approach is applicable to both monoclonal and polyclonal immunoglobulins, albeit epitopes bound by monoclonal antibodies can be in general mapped with higher reliability. Mapping of linear epitopes is fairly straightforward, whereas identification of conformational ones requires computational analysis of data and tends to be subjective. Nevertheless, the predicted conformational epitope recognized by the neutralizing antibody against CCL2 agrees well with the data on surface residues crucial for binding to cognate receptor from mutagenesis studies.

\section{Experimental}

\section{1 Phage Library Screening}

Phage-displayed random peptide libraries were panned against individual antibodies (Table 1) essentially as previously described. ${ }^{16}$ Each antibody was probed with a library of linear (Ph.D.-12) and cyclized peptides (Ph.D.-C7C; New England Biolabs). Bound phages were eluted with acidic buffer. After 3 rounds of affinity selection individual clones were screened by ELISA for binding to target antibody. Oligonucleotide inserts encoding displayed peptides were sequenced to reveal epitope mimetics.

\section{2. Mapping of Epitope Mimetics to Antigen Structure}

For linear epitopes, peptides were aligned to antigens' primary structure. Peptides selected against antibody ab18678 showed no significant homology to CCL2 and were inferred to represent mimetics of conformational epitope. They were mapped to structural model of CCL2 (PDB code 3IFD), ${ }^{17}$ using Pepitope ${ }^{14}$ and Episearch servers. ${ }^{15}$

\section{3. Recombinant CCL2 Expression}

Human CCL2 gene ${ }^{18}$ (plasmid ID HsCD00001488) was procured from Harvard PlasmID Database, subcloned into the pET44 plasmid and expressed in Escherichi coli BL21 DE3 with C-terminal His-tag. Cells were lysed by sonication and lysate was diluted in $20 \mathrm{mM}$ phosphate $\mathrm{pH}$ 7.4, $4 \mathrm{M}$ guanidinuim chloride, $10 \mathrm{mM}$ imidazole. Lysate was filtered and denatured CCL2 in monomeric form was isolated using immobilized-metal affinity chromatography (HisTrap column) followed by denaturing sizeexclusion chromatography (dSEC; Sephacryl S200 16/60 HR column) on Äkta Explorer 10 FPLC System (GE Healthcare). Finally, CCL2 was refolded using dialysis against a series of $20 \mathrm{mM}$ phosphate buffers $\mathrm{pH} 7.4$ with initial glutathione content $(2 \mathrm{mM}$ and $0.4 \mathrm{mM}$ reduced and oxidized form, respectively) and progressively lowering guanidinium concentration from 4 to $0 \mathrm{M}$ over 2 days. Refolded CCL2 was analyzed by SEC (Superdex S-200 10/300 column, GE Healthcare) and CD spectroscopy (62A DS spectrometer, Aviv Biomedical); data not shown.

Table 1: Antibodies used as targets in affinity selection experiments.

\begin{tabular}{lllll}
\hline Antigen & Company & Catalogue No. & Clone & Host/IgG isotype \\
\hline ghrelin & Santa Cruz & sc-10368 & polyclonal & goat \\
& Biotechnology & (in-house affinity purified) & & \\
leptin & R\&D Systems & MAB398 & 44802 & mouse/IgG1 \\
& R\&D Systems & AF-398 & polyclonal & goat \\
CCL2 & Abcam & ab9669 & polyclonal & rabbit \\
& Abcam & ab18678 & S101 & mouse/IgG1 \\
& R\&D Systems & AF-279-NA & polyclonal & goat \\
\hline
\end{tabular}




\section{4. Immuno-dot-blot Assay to Confirm Conformational Nature of Epitope Recognized by Antibody ab18678}

Four 5-fold dilutions of recombinant CCL2 were prepared either in PBS buffer alone or PBS supplemented with $1 \%$ sodium dodecyl sulfate and $100 \mathrm{mM}$ dithiothreitol. Two microliters of each dilution were spotted on a 1 $\mathrm{cm}$ strip of nitrocellulose membrane and probed with either ab9669 or ab18678 at $1 \mu \mathrm{g} / \mathrm{mL}$, and detected with secondary antibodies (goat anti-rabbit IgG-HRP conjugate
(Millipore) or goat anti-mouse IgG/A/M-HRP conjugate (Thermo Fischer), respectively).

\section{Results and Discussion}

In this study, we set out to map epitopes of 3 model polypeptide antigens as recognized by different neutralizing antibodies using phage-displayed random peptide libraries' screening. All the antibodies were raised against whole recombinant proteins, therefore no assumptions on

CCL2

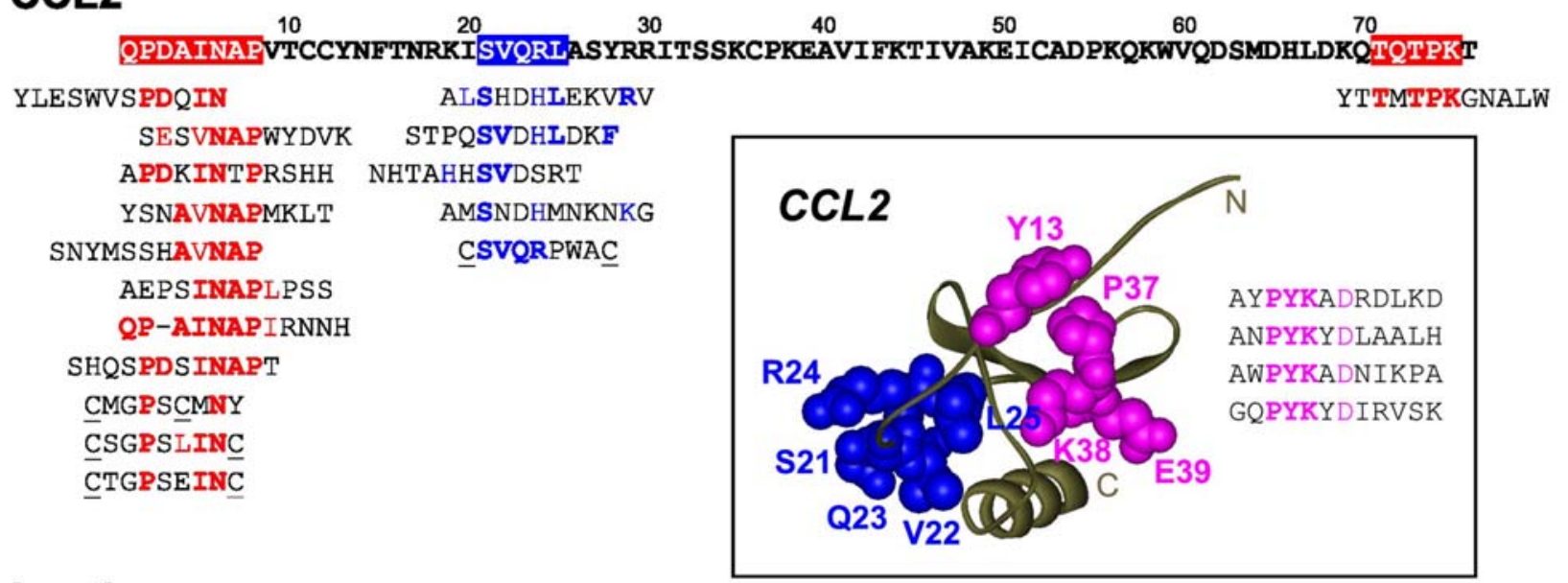

\section{Leptin}

$\underline{\text { CPPQKAHHC }}$

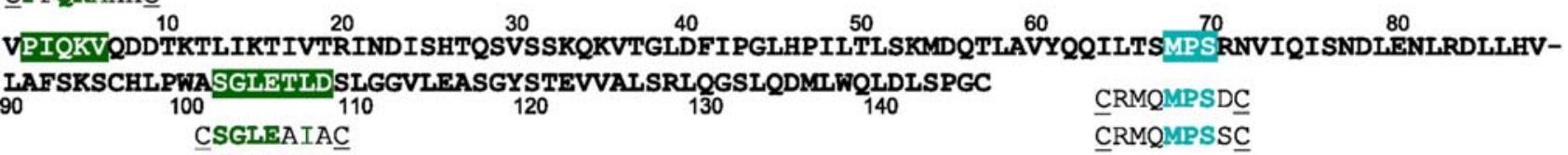

CSGIEALAC

$\underline{\text { CLERLGFWC }}$

CFETLDKW드

QFPYGFFCETCES

\section{Ghrelin}

10
GSSFLSPEHQRV 20
GAGKHESKKPPAKLQPR
NLENRKPPYVPI
WDINERPKPKQH
ASHPHNEWKKPP
FAENTKPPITYR
YSLENLKPPTSR
Q-APYRDESHKPP
CKPGYTHSC
CKPGYQDSC
CKSEIQQKC

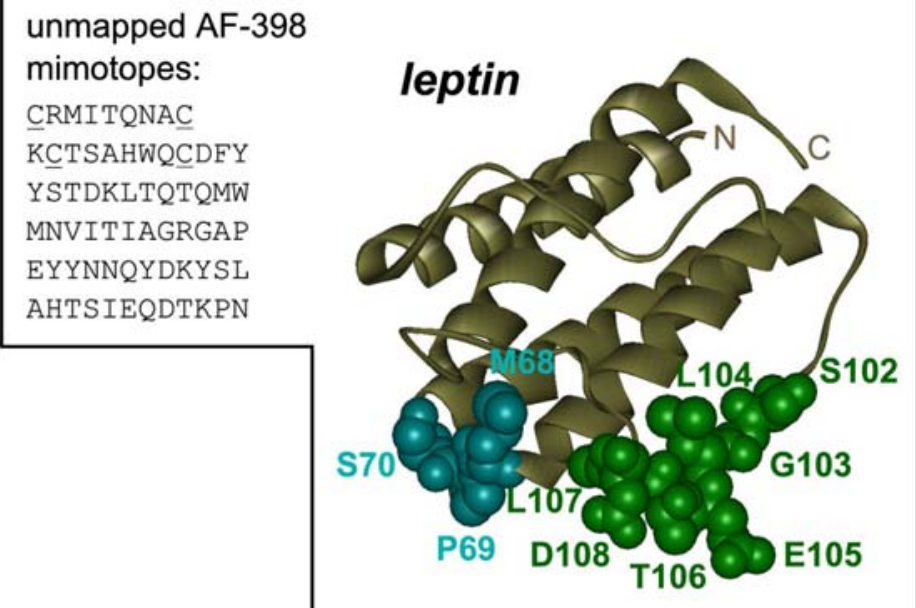

Figure 1: Affinity-selected epitope-mimicking peptides mapped to antigens' structures. Epitopes recognized by individual antibodies are color coded: red - ab9669, blue - AF-279-NA, pink - ab18678, green - AF-398, turquoise - MAB398, violet - sc-10368. In cyclized peptides cysteines forming disulfide bonds are underlined. Antigenic determinants bound by AF-279-NA, ab18678, AF-398 and MAB398 are depicted as space-filling models on ribbon diagrams of CCL2 (PDB code 3IFD) ${ }^{17}$ and leptin (PDB code 1AX8). ${ }^{21}$ 
epitope structure that they interact with could be made in advance. Each target was probed with 2 libraries; one containing random dodecapeptides, and the other comprising conformationally constrained cyclic peptides of the $\mathrm{CX}_{7} \mathrm{C}$ general structure, where $X$ is any of the 20 proteinogenic amino acids. We reasoned that cyclization might be beneficial in certain cases as some cyclized peptides efficiently mimic secondary structural elements ${ }^{19}$ or engage into stronger interactions due to preorganized binding structure (resulting in thermodynamically favorable lower loss of entropy). ${ }^{20}$

Affinity selected peptides aligned to cognate antigens' structure are depicted in Fig. 1. With the exception of monoclonal antibody ab18678, all the antibodies appear to bind linear epitopes. In panning experiments against the polyclonal antibody AF-398 we enriched a number of peptides that presumably mimic leptin's discontinuous determinants alongside linear epitope mimetics. It is plausible that subpopulations of other polyclonal antibodies, especially the ones directed against proteins with well-defined tertiary structures (i.e., ab9669 and AF279-NA), recognize conformational epitopes as well, even though we failed to detect their mimetics. Indeed, it is very likely that in screening phage libraries against a pool of antibodies, peptide mimetics of linear epitopes are preferentially selected.

Peptide hormone ghrelin lacks a well-defined secondary structure in solution, ${ }^{22}$ thus we expected the polyclonal antibody sc-10368 to recognize solely linear epitopes. Indeed, the epitope was mapped to an internal region of ghrelin with the motif ExxKPP most strongly enriched in affinity-selected peptides. Alongside 7 linear and one cyclic peptide that recapitulated the epitope well, 2 structurally related cyclic peptides with relatively low homology to ghrelin were identified. The latter were considered typical mimotopes (i.e., their constrained structure presumably fits the antibody paratope despite poor sequence similarity to the true epitope). ${ }^{23}$

Polyclonal antibody ab9669 binds to unstructured $\mathrm{N}$ - and C-termini of CCL2. The N-terminal residues of CCL2 were previously shown to be crucial for receptor activation, ${ }^{24,25}$ which would explain the neutralizing nature of antibody. Again, several linear peptides were identified that map well to the N-terminal segment of the chemokine, while cyclized mimotopes display only weak resemblance to primary structure of CCL2.

Antibodies AF-279-NA and MAB398 recognize linear epitopes - loops in CCL2 and leptin, respectively. Affinity selections against AF-279-NA yielded 4 linear and a cyclic peptide. The cyclized peptide better recaps the determinant, indicating the importance of cysteines for loop mimicry. Previous mutagenesis analysis of CCL2 showed that Arg24 located within the loop plays an important role in receptor binding, ${ }^{25}$ revealing why AF-279NA neutralizes CCL2 activity. For monoclonal antibody MAB398 only cyclized peptide epitope mimetics of the short loop that connects helices B and C of leptin were identified. As this segment of the hormone does not directly contact leptin receptor, ${ }^{26}$ we assume that MAB398 neutralizes leptins's activity via sterically blocking adjacent receptor-interacting residues located in helix C.

Twelve peptides binding to anti-leptin polyclonal antibody AF-398 were identified, among which one was mapped to the unstructured $\mathrm{N}$-terminus and 5 to the long loop connecting helices $\mathrm{C}$ and $\mathrm{D}$. All loop epitope-mimicking peptides were cyclic; even the one selected from random dodecapeptide library contained a pair of cysteines, suggesting this feature was crucial for peptides to adopt this specific conformation. In addition, panning to AF-398 gave 6 peptides that bore no homology to leptin nor were they similar to each other. Lack of any consensus motif, likely because the peptides mimicked different determinants, made reliable mapping of these mimotopes impossible and they were not pursued further. Assaying and sequencing a larger number of phage clones following affinity selection or applying parallel sequencing technology to characterize pools of enriched phage clones might still lead to identification of sets of structurally related peptides from which one could attempt to identify epitopes computationally.

Screening of peptide libraries against the monoclonal antibody ab18678 resulted in enrichment of 4 linear peptides that could not be aligned to CCL2 amino acid sequence but shared the consensus motif PYK(A/Y)D. To check whether the antibody recognizes linear or conformational epitope (and hence whether the identified pepti-

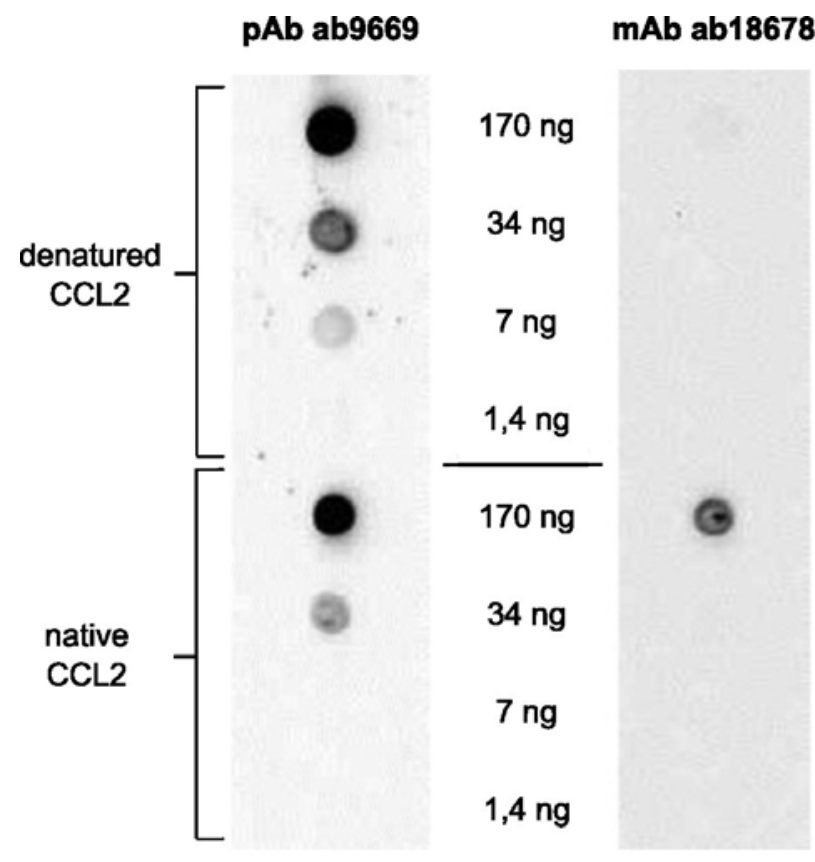

Figure 2: Immuno-dot-blot assay of polyclonal antibody (pAb) ab9669 and monoclonal antibody (mAb) ab18678 interaction with denatured and native forms of recombinant CCL2. 
des are mimotopes of linear or discontinuous determinant), we expressed the antigen in $E$. coli and performed a dot-blot assay of ab18678 interaction with the native and denatured CCL2 (Fig. 2). The monoclonal antibody only bound the native antigen, suggesting that the epitope was conformational. In comparison, the polyclonal antibody ab9669 also bound CCL2 in denatured form. In fact, this antibody produced higher signals when exposed to denatured CCL2, which is in agreement with its epitopes being linear.

To identify from affinity selected peptide mimotopes the residues on CCL2 that form the functional epitope recognized by ab18678, we resorted to computational analysis. We used 2 programs that use different algorithms for mapping sets of peptides, binding to antibody paratopes, onto a three-dimensional structure of antigens; Episearch ${ }^{15}$ and Pepitope. ${ }^{14}$ Both singled out the same set of 3 surface exposed residues on CCL2; Pro37 and Lys38 contained within the loop connecting the first and the second beta sheet, and the adjacent Tyr13), while Episearch additionally proposed that aspartic acid in enriched motif might mimic Glu39. Among these residues, Y13 is absolutely essential for CCL2 binding to its cognate receptor as Y13 conversion to alanine reduced affinity by 2 orders of magnitude compared to the wild-type chemokine. ${ }^{25}$ Mutation of Lys38 had a smaller but still measurable effect. ${ }^{25}$ The predicted conformational epitope is thus supported by mutagenesis data on CCL2 biological activity.

\section{Conclusions}

We panned phage-displayed libraries of random peptides against a number of model antibodies to identify their cognate epitopes. Epitopes recognized by monoclonal antibodies were reliably mapped to protein antigens' structure even when the epitope was conformational. Polyclonal antibodies by definition interact with diverse epitopes of a single antigen and indeed we typically enriched sets of structurally unrelated peptides in experiments where polyclonal antibodies were used as targets. While mapping of linear epitope mimetics recognized by polyclonal antibodies was straightforward, mimotopes of conformational epitopes turned out to be rather challenging. This was due to lack of any amino acid consensus motif in enriched peptides which likely suggest mimicry of different epitopes. We note that with most polyclonal antibodies mimetics of linear epitopes were preferentially selected. Even though we failed to enrich mimetics of conformational epitopes with some polyclonal antibodies, we cannot rule out that their subpopulations do bind discontinuous determinants.

Finally, we demonstrate the importance of screening peptide libraries of different designs, such as constrained and non-constrained peptides, when attempting to map epitopes. While some epitopes were preferentially mimic- ked by linear peptides, others (typically linear epitopes harbored within loops) were efficiently recapped only by cyclized peptides.

In conclusion, screening of random peptide phage libraries against antibodies is a convenient approach to map cognate epitopes. It is fast (takes less than 2 weeks) and relatively inexpensive compared to alternative methods which either require sophisticated equipment or extensive labor input to produce antigen-specific tools for epitope mapping (e.g. antigen muteins, gene fragment or peptide fragment libraries). We therefore suggest the described approach be tried initially when characterizing antibodies. Complementary methods should later be used to validate the deduced epitopes.

\section{References}

1. N. D. Rubinstein, I. Mayrose, D. Halperin, D. Yekutieli, J. M. Gershoni, T. Pupko, Mol. Immunol. 2008, 45, 34773489. http://dx.doi.org/10.1016/j.molimm.2007.10.016

2. J. Novotny, Mol. Immunol. 1991, 28, 201-207. http://dx.doi.org/10.1016/0161-5890(91)90062-O

3. J. C. Geoghegan, G. Diedrich, X. Lu, K. Rosenthal, K. F. Sachsenmeier, H. Wu, W. F. Dall'Acqua, M. Damschroder, MAbs 2016.

http://dx.doi.org/10.1080/19420862.2016.1143182

4. V. Oganesyan, L. Peng, R. M. Woods, H. Wu, W. F. Dall'Acqua, J. Biol. Chem. 2015, 290, 14979-14985. http://dx.doi.org/10.1074/jbc.M115.652156

5. J. M. Gershoni, A. Roitburd-Berman, D. D. Siman-Tov, N. Tarnovitski Freund, Y. Weiss, BioDrugs 2007, 21, 145-156. http://dx.doi.org/10.2165/00063030-200721030-00002

6. J. B. Legutki, S. A. Johnston, Proc. Natl. Acad. Sci. U S A, 2013, 110, 18614-18619. http://dx.doi.org/10.1073/pnas.1309390110

7. N. Clementi, N. Mancini, M. Castelli, M. Clementi, R. Burioni, Drug Discov. Today 2013, 18, 464-471. http://dx.doi.org/10.1016/j.drudis.2012.11.006

8. R. Menez, M. Bossus, B. H. Muller, G. Sibai, P. Dalbon, F. Ducancel, C. Jolivet-Reynaud, E. A. Stura, J. Immunol. 2003, 170, 1917-1924. http://dx.doi.org/10.4049/jimmunol.170.4.1917

9. D. C. Benjamin, S. S. Perdue, Methods 1996, 9, 508-515. http://dx.doi.org/10.1006/meth.1996.0058

10. S. Dhungana, J. G. Williams, M. B. Fessler, K. B. Tomer, Methods Mol. Biol. 2009, 524, 87-101. http://dx.doi.org/10.1007/978-1-59745-450-6_7

11. H. M. Geysen, R. H. Meloen, S. J. Barteling, Proc. Natl. Acad. Sci. U S A 1984, 81, 3998-4002. http://dx.doi.org/10.1073/pnas.81.13.3998

12. F. Fack, B. Hugle-Dorr, D. Song, I. Queitsch, G. Petersen, E. K. Bautz, J. Immunol. Methods 1997, 206, 43-52. http://dx.doi.org/10.1016/S0022-1759(97)00083-5

13. V. Bottger, A. Bottger, Methods Mol. Biol. 2009, 524, 181201. http://dx.doi.org/10.1007/978-1-59745-450-6_13 
14. I. Mayrose, O. Penn, E. Erez, N. D. Rubinstein, T. Shlomi, N. T. Freund, E. M. Bublil, E. Ruppin, R. Sharan, J. M. Gershoni, E. Martz, T. Pupko, Bioinformatics 2007, 23, 3244 3246. http://dx.doi.org/10.1093/bioinformatics/btm493

15. S. S. Negi, W. Braun, Bioinform. Biol. Insights 2009, 3, 71-81.

16. T. Bratkovič, M. Lunder, T. Popovič, S. Kreft, B. Turk, B. Štrukelj, U. Urleb, Biochem. Biophys. Res. Commun. 2005, 332, 897-903.

http://dx.doi.org/10.1016/j.bbrc.2005.05.028

17. T. L. Grygiel, A. Teplyakov, G. Obmolova, N. Stowell, R. Holland, J. F. Nemeth, S. C. Pomerantz, M. Kruszynski, G. L. Gilliland, Biopolymers 2010, 94, 350-359. http://dx.doi.org/10.1002/bip.21390

18. A. E. Witt, L. M. Hines, N. L. Collins, Y. Hu, R. N. Gunawardane, D. Moreira, J. Raphael, D. Jepson, M. Koundinya, A. Rolfs, B. Taron, S. J. Isakoff, J. S. Brugge, J. LaBaer, J. Proteome Res. 2006, 5, 599-610. http://dx.doi.org/10.1021/pr050395r

19. H. Yin, ISRN Biochem. 2012, 2012, 692190. http://dx.doi.org/10.5402/2012/692190

20. S. H. Joo, Biomol. Ther. (Seoul) 2012, 20, 19-26. http://dx.doi.org/10.4062/biomolther.2012.20.1.019
21. F. Zhang, M. B. Basinski, J. M. Beals, S. L. Briggs, L. M. Churgay, D. K. Clawson, R. D. DiMarchi, T. C. Furman, J. E. Hale, H. M. Hsiung, B. E. Schoner, D. P. Smith, X. Y. Zhang, J. P. Wery, R. W. Schevitz, Nature 1997, 387, 206209. http://dx.doi.org/10.1038/387206a0

22. M. V. Silva Elipe, M. A. Bednarek, Y. D. Gao, Biopolymers 2001, 59, 489-501. http://dx.doi.org/10.1002/1097-0282(200112)59:7<489: :AID-BIP1054>3.0.CO;2-S

23. H. M. Geysen, S. J. Rodda, T. J. Mason, Mol Immunol 1986, 23, 709-715. http://dx.doi.org/10.1016/0161-5890(86)90081-7

24. Y. Zhang, B. J. Rollins, Mol. Cell Biol. 1995, 15, 4851-4855. http://dx.doi.org/10.1128/MCB.15.9.4851

25. S. Hemmerich, C. Paavola, A. Bloom, S. Bhakta, R. Freedman, D. Grunberger, J. Krstenansky, S. Lee, D. McCarley, M. Mulkins, B. Wong, J. Pease, L. Mizoue, T. Mirzadegan, I. Polsky, K. Thompson, T. M. Handel, K. Jarnagin, Biochemistry 1999, 38, 13013-13025. http://dx.doi.org/10.1021/bi991029m

26. F. Peelman, K. Van Beneden, L. Zabeau, H. Iserentant, P. Ulrichts, D. Defeau, A. Verhee, D. Catteeuw, D. Elewaut, J. Tavernier, J. Biol. Chem. 2004, 279, 41038-41046. http://dx.doi.org/10.1074/jbc.M404962200

\section{Povzetek}

Poznavanje antigenskih determinant je ključnega pomena v zgodnjem razvoju terapevtskih in diagnostičnih protiteles, pri vrednotenju učinkovitosti klasičnih ali razvoju epitopnih cepiv. Večina metod za kartiranje epitopov protiteles je dragih in eksperimentalno zahtevnih. V pričujoči raziskavi smo ocenjevali primernost afinitetnega presejanja knjižnic naključnih peptidov, predstavljenih na bakteriofagih, kot orodja za identifikacijo epitopov. Kot tarče v afinitetnih selekcijah smo uporabili šest različnih mono- in poliklonskih protiteles proti trem modelnim proteinom. Ugotovili smo, da pristop omogoča jasno identifikacijo linearnih epitopov, medtem ko je kartiranje konformacijskih epitopov bolj zahtevno, saj je manj zanesljivo in zahteva uporabo računalniških orodij. Kljub temu je s podrobnim poznavanjem antigena (npr. $\mathrm{z}$ analizo vpliva mutacij na aktivnost proteinskega antigena) na osnovi peptidnih mimetikov tudi konformacijske epitope mogoče napovedati s precejšnjo zanesljivostjo. Ker opisan pristop omogoča hitro in poceni razkritje epitopov, predlagamo njegovo uporabo v zgodnjih fazah razvoja protiteles s kasnejšo validacijo antigenskih determinant $\mathrm{s}$ komplementarnimi metodami. 